\title{
Prolonged Indwelling Foley Catheter Use in Post-operative Gynecology Patient Associated with an Increased Incidence of Urinary Tract Infections
}

\author{
Edy Ardiansyah*, Arvitamuriany Triyanthi Lubis, Mohammad Iman Syahputra \\ Department of Obstetrics and Gynecology, Faculty of Medicine, Universitas Sumatera Utara, Medan, Indonesia
}

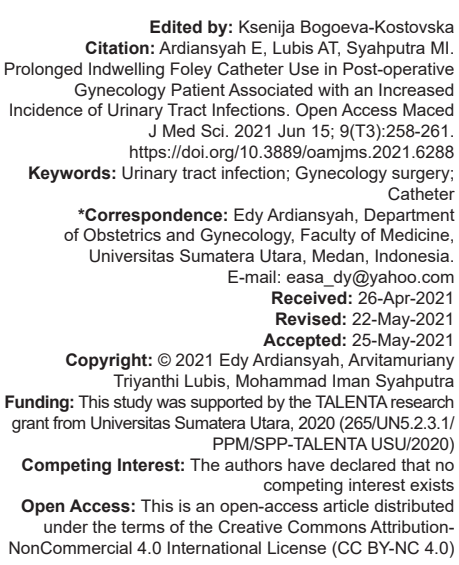

Edited by: Ksenija Bogoeva-Kostovska Citation: Ardiansyah E, Lubis AT, Syahputra ML. Indwelling Foley Catheter Use in Post-operative Gynecology Patient Associated with an Increase Incidence of Urinary Tract Infections. Open Access Maced J Med Sci. 2021 Jun 15; 9(T3):258-261. https://doi.org/10.3889/oamjms.2021.628 Keywords: Urinary tract infection; Gynecology surgery;

*Correspondence: Edy Ardiansyah, Department of Obstetrics and Gynecology, Faculty of Medicine, Universitas Sumatera Utara, Medan, Indonesia. E-mail: easa_dy@yahoo.com
Received: 26-Apr-2021 Revised: 22-May-202 Accepted: 25-May-202

Copyright: ๑ 2021 Edy Ardiansyah, Arvitamuriany Triyanthi Lubis, Mohammad Iman Syahputra Funding: This study was supported by the TALENTA research grant from Universitas Sumatera Utara, 2020 (265/UN5.2.3.1 Competing Interest: The authors have declared that rome in Open Access: This is an open-access article distributed under the terms of the Creative Commons AtributionNonCommercial 4.0 International License (CC BY-NC 4.0)

\begin{abstract}
BACKGROUND: Urinary tract infection (UTI) is one of the common conditions and significantly contributes to expensive health treatment and associated with gynecological surgery which increases the cases up to $50 \%$ in women undergoing specific reconstructive procedures. Besides that, one indicator of surgical quality was postoperative UTI occurrence.

AIM: This study aims to assess the relationship between Foley catheter usage and UTIs after gynecological surgery with a urinary catheter.

METHODS: A total of 48 subjects examined at the Department of Obstetrics and Gynecology, Universitas Sumatera Utara Hospital, and Haji Adam Malik General Hospital, Medan, from June to September 2020. Subjects were performed urinalysis 8 days after surgery, or earlier if UTI symptoms occur. Personal data and illness data were taken from medical records. Statistical analysis was done using the Chi-square-based test.

RESULTS: There was a significant difference of urine leukocytes in subjects with indwelled catheter for 24-36 h compared to subjects with $36-48 \mathrm{~h}$ of catheterization $(\mathrm{p}=0.01)$. The $36-48 \mathrm{~h}$ group has a 2.15 odds of developing UTI compared to $24-36 \mathrm{~h}$ group $(p=0.01)$

CONCLUSION: This study found that prolonged indwelling Foley catheter usage may increase the risk of UTI afte
\end{abstract} gynecology surgery.

\section{Introduction}

One of the common conditions and significantly contributes to expensive health treatment was urinary tract infection (UTI), costing more than 5 billion dollars in 2010. Women were more susceptible than man because of anatomical and physiological differences. Half of all women experience at least one UTI in their lifetime, and more than $10 \%$ of postmenopausal women experience recurrent UTIs. Risk of UTI was increased up to $50 \%$ because of history of gynecology surgery. Therefore, it is important to assess possibility of UTI in women after gynecological surgery to predict and choose outpatient care and inpatient care in a health facility. For example, health-care cost was significantly decrease after reduction of post-operative UTI after pelvic surgery [1], [2], [3].

One of the best indicators for surgical quality was UTI occurrence. In 2012, both the Center for Health Services and the Joint Commission on Health Organization Accreditation recommend all healthcare providers to report rates of surgical site infection including UTIs in a public registry [4], [5], [6], [7]. Marker qualities for gynecological surgery must include assessment of post-operative UTI which is needed to be more evaluated by various reports of post-operative UTI incidence. But for now, study that discusses this matter was limited, and it cannot describe post-operative UTI as one of the best predictors for gynecology surgery and assess the risk factor about it [5], [8], [9], [10], [11]. Hence, this research was aimed to show proportion of women whom developed a UTI within 8 days of gynecological surgery. We hypothesize that there are independent risk factors associated with UTI after gynecological surgery.

\section{Methods}

This research is an observational study with a prospective cohort design. The research subjects were all patients that underwent gynecologic surgery at the Department of Obstetrics and Gynecology in Universitas Sumatera Utara Hospital and Adam Malik General Hospital, Medan, from June to September 2020 which was met the inclusion and exclusion criteria. Candidates have signed informed consent as evidence of their willingness to be research subjects. 
Patients who came to the obstetric gynecology clinic at Universitas Sumatera Utara Hospital and Adam Malik General Hospital were interviewed about the history of the disease, basic examinations, body weight, height, previous medical history, physical examination, supporting examinations, and admission diagnosis were obtained. Before surgery, urine and blood samples were taken for examination of complete blood, blood sugar levels, kidney function, and urinalysis. The duration of indwelled urinary catheter usage during hospitalization was recorded. On the $8^{\text {th }}$ day post-surgery, urinalysis was performed or sooner if the patient reported UTI symptoms. Data were analyzed using the Chi-square test, with $p<$ 0.05 considered significant (95\% confidence interval [Cl]). This study was approved by Health Research Ethical Committee, Medical Faculty, Universitas Sumatera Utara.

\section{Results}

The results of the study in the period of June 2020 to September 2020, 63 patients underwent postgynecological surgery catheters at the Universitas Sumatera Utara Hospital and Haji Adam Malik General Hospital. The data obtained were entered into a computer, then compiled and tabulated and presented in tabular and narrative form. Of the 33 research subjects, it was obtained catheter installation for 24-36 $\mathrm{h}$ for the results (-) as many as 15 people or $62.5 \%$ and (+) as many as 9 people or $37.5 \%$. Catheter placement for 36-48 $\mathrm{h}$ where the results (-) were 5 people or $20.8 \%$, (+) were 15 people or $62.5 \%$, and $(++)$ were 4 people or $16.7 \%$. There is a significant or statistically significant difference. Thus, it can be explained that there is a statistically significant difference between the variable insertion of 24-36 h catheter insertion group compared with the 36-48 $\mathrm{h}$ group.

Table 1: Characteristics of subjects in research

\begin{tabular}{ll}
\hline Variable & Variable, $\mathrm{n}(48)$ \\
\hline Age (Mean \pm SD) & $40.9(12.6)$ \\
Duration of surgery $(\mathrm{n}, \%)$ & \\
$<4 \mathrm{~h}$ & $43(79.2 \%)$ \\
$>4 \mathrm{~h}$ & $5(20.8 \%)$ \\
\hline
\end{tabular}

Table 2: Results of urine leukocytes with catheter insertion group 24-36 $\mathrm{h}$ and 36-48 $\mathrm{h}$

\begin{tabular}{llll}
\hline Variable & \multicolumn{2}{l}{ Group } & p-value \\
\cline { 2 - 3 } & $24-36 \mathrm{~h}$ & $36-48 \mathrm{~h}$ & \\
\hline Leukocytes urine & $15(62.5 \%)$ & $5(20.8 \%)$ & 0.01 \\
- & $9(37.5 \%)$ & $15(62.5 \%)$ & \\
+ & 0 & $4(16.7 \%)$ & \\
++ & &
\end{tabular}

Characteristics of the overall subjects of the study patients according to age with mean $40.9 \pm 12.6$. Most of the operation time was $<4 \mathrm{~h}$ as many as 26 people or by $79.2 \%$ and more than hours as many as 7 people (20.8\%) (Table 1). After analyze with Chi-square test, the results obtained $p=0.01(p<0.05)$ which indicated a significant relationship between urine leukocyte and catheter placement for 24-36 h and 36-48 h (Table 2).
Then, Chi-square tested was also done to assess the association of UTI incidence with catheter placement for 24-36 $\mathrm{h}$ and 36-48 $\mathrm{h}$ using and the results obtained $p=0.01(p<0.05)$ which indicated a significant relationship (Table 3 ).

Table 3: Results of UTI with catheter insertion group 24-36 h and 36-48 $\mathrm{h}$

\begin{tabular}{lllll}
\hline UTI & Group & & OR & p-value* \\
\cline { 2 - 3 } & $24-36 \mathrm{~h}$ & $36-48 \mathrm{~h}$ & & \\
\hline No & $15(62.5 \%)$ & $5(20.8 \%)$ & 2.15 & 0.01 \\
Yes & $9(37.5 \%)$ & $19(79.2 \%)$ & & \\
\hline${ }^{*}$ Chi-square test, UTI: Urinary tract infection & & &
\end{tabular}

\section{Discussion}

The data in Table 1 described the characteristics of the overall study patients according to age and duration of the surgery. For age of subjects, the average is $40.9 \pm 12.6$. For the duration of surgery, the majority of subjects (43 subjects or $79.2 \%$ ) underwent surgery for $4 \mathrm{~h}$ or less. From Table 2, 15 subjects (62.5\%) from 24-36 h group had negative results for urine leukocyte, and 9 subjects $(37.5 \%)$ had a positive result of urine leukocyte. While from $36-48$ h group, 5 subjects $(20.8 \%)$ had a negative result for urine leukocyte and 19 subjects $(79.2 \%)$ had a positive result for urine leukocyte. There is a significant or statistically significant difference between the two groups $(p<0.01)$. These findings reinforce previous research which states that the highest incidence rate of UTIs occurs on the $2^{\text {nd }}$ day of catheter usage [4], [5], [6]. From Table 3, 15 subjects (62.5\%) from 24-36 h group had negative results for urinary tract infection, and 9 subjects $(37.5 \%)$ had positive result of urinary tract infection. While from $36-48 \mathrm{~h}$ group, 5 subjects $(20.8 \%)$ had a negative result urinary infection and 19 subjects $(79.2 \%)$ had a positive result for urine tract infection. From the analysis, we found that there is 2.15 times risk for UTIs occurs on the $2^{\text {nd }}$ day of catheter usage $(p<0.01)$.

A study by Qin et al. demonstrated that surgical procedures of longer duration were independently associated with an increased risk of UTIs (OR, 1.156 [95\% Cl 1.104-1.21]; OR, 1.758 [95\% Cl 1.682-1.838]) while procedures of shorter duration were associated with a reduced risk (OR, 0.928 (95\% Cl 0.873-0.987); OR, 0.955 (95\% Cl 0.906- 1.007) [14]. Choudury's study of women after urogenital prolapse surgery showed that urine culture was positivity which was found in $16 \%$ in the long-term catheterization group (> 5 days) compared with $6 \%$ in the short-term ( 1 day) group ( $p=0.02$ ). The duration of hospitalization was 6.98 days in the long-term catheterization group and 4.68 days in the short-term catheterization group ( $p<0.01)$. The residual volume was more than $200 \mathrm{ml}$ and the need for recatheterization occurred in $3 \%$ of the 
group while in $10 \%$ group of cases $(p=0.04)$ [15]. Critical appraisal of clinical trial articles to assess about $24 \mathrm{~h}$ post-operative urinary catheter removal found that subjects in earlier removal $(<24 \mathrm{~h})$ groups were 3-4 times more likely to have recatheterization $(\mathrm{OR}=3.10-4.0)$ compared to later removal groups, while they who have it removed on the $5^{\text {th }}$ day were 14 times more likely to develop UTI compared with immediate group $(\mathrm{OR}=14.786,95 \% \mathrm{Cl} 3.187-$ 68.595) [16]. When compared with $>6 \mathrm{~h}$ indwelling urinary catheter removal group, the incidence of urinary infection was significantly reduced at the $<6 \mathrm{~h}$ removal group $(\mathrm{RR}=0.66,95 \% \mathrm{Cl} 0.48-0.89$, $\mathrm{p}=0.007)$. The urinary catheter removal time at $<6 \mathrm{~h}$ also significantly reduced the incidence of urinary retention $(\mathrm{RR}=5.06,95 \% \mathrm{Cl} 1.74-14.69, \mathrm{p}=0.003$ ) and did not statistically increase the incidence of urinary infection $(R R=0.30,95 \% \mathrm{Cl} 0.08-1.20$, $p=0.09)$, compared with immediate urinary catheter removal after surgery [17].

Kranz et al. reported that the catheterassociated UTI rate was $65 \%$ lower when catheters were regularly changed (monthly and/or when medically indicated vs. only when medically indicated) (RR: 0.35 ; [0.13; 0.95]). The incidence of bacteriuria in medical facilities rises by 3-8\% per day for each day after catheter insertion; nearly, all patients have bacteriuria after 30 days of catheterization. Overall, catheter-associated bacteremia accounts for $15 \%$ of nosocomial bloodstream infections and is associated with $10 \%$ mortality [18]. The limitation of this study is the subjectivity factor in determining urine leukocytes on the dipstick because it is determined based on quality, not quantity. For advice, it is best if the urine leukocyte results are confirmed quantitatively in the laboratory.

\section{Conclusion}

In the group of subjects with catheter insertion for $36-48 \mathrm{~h}$, there was an increased incidence of increased urinary leukocytes compared to the group of subjects with 24-36 h post-operative catheter placement.

\section{AQ6 References}

1. Dieter AA, Amundsen CL, Edenfield AL, Kawasaki A, Levin PJ, Visco $A G$, et al. Oral antibiotics to prevent postoperative urinary tract infection: A randomized controlled trial Obstet Gynecol. 2014;123(1):96-103. https://doi.org/10.1097/ aog. 0000000000000024

\section{PMid:24463669}

2. Chai J, Pun TC. A prospective randomized trial to compare immediate and 24-hour delayed catheter removal following total abdominal hysterectomy. Acta Obstet Gynecol Scand. 2011;90(5):478-82. https://doi. org/10.1111/j.1600-0412.2011.01104.x

PMid:21332450

3. Chang R, Greene MT, Chenoweth CE, Kuhn L, Shuman E, Rogers MA, et al. Epidemiology of hospital-acquired urinary tract-related bloodstream infection at a university hospital. Infect Control Hosp Epidemiol. 2011;32(11):1127-9. https://doi. org/10.1086/522266

PMid:22011543

4. Eduardo JC, Alves DS, Hinden IE, Toledano IP, Freitas SG, Mondino PJ, et al. Urinary tract infection and indwelling urinary catheters: Prospective study in gynecological surgery with antibiotic prophylaxis. Sao Paulo Med J. 2015;133(6):517-20. https://doi.org/10.1590/1516-3180.2014.9071412

PMid:26465812

5. El-Nashar SA, Singh R, Schmitt JJ, Leon DC, Arora C, Gebhart JB, Occhino JA. Urinary Tract infection after hysterectomy for benign gynecologic conditions or pelvic reconstructive surgery. Obstet Gynecol. 2018;132(6):1347-57. https://doi.org/10.1097/aog.0000000000002931

PMid:30334857

6. Enomoto LM, Hollenbeak CS, Bhayani NH, Dillon PW, Gusani NJ. Measuring surgical quality: A national clinical registry versus administrative claims data. J Gastrointest Surg. 2014;18(8):1416-22. https://doi.org/10.1016/j.jss.2013.11.574 PMid:24928187

7. Fattah AN, Santoso BI. Urinary catheterization in gynecological surgery: When Should it be Removed? Med J Indones. 2013;22(3):183-8. https://doi.org/10.13181/mji.v22i3.589

8. Ghafourian S, Sekawi Z, Neela V, Khosravi A, Rahbar M, Sadeghifard $\mathrm{N}$. Incidence of extended-spectrum betalactamase-producing Klebsiella pneumoniae in patients with urinary tract infection. Sao Paulo Med J. 2012;130(1):37-43. https://doi.org/10.1590/s1516-31802012000100007

PMid:22344358

9. Lake AG, McPencow AM, Dick-Biascoechea MA, Martin DK Erekson EA. Surgical site infection after hysterectomy. Am J Obstet Gynecol. 2013;209(5):490.e1-9. https://doi.org/10.1097/ ogx.0b013e3182a8507f PMid:23770467

10. Lusardi G, Lipp A, Shaw C. Antibiotic prophylaxis for short-term catheter bladder drainage in adults. Cochrane Database Syst Rev. 2013;2013(7):CD005428. https://doi. org/10.1002/14651858.cd005428.pub2

PMid:23824735

11. Weemhoff M, Wassen M, Korsten L, Serroyen J, Kampschöer $P$, Roumen F. Postoperative catheterization after anterior colporrhaphy: 2 versus 5 days. A multicentre randomized controlled trial. Int Urogynecol J. 2011;22(4):477-83. https://doi. org/10.1007/s00192-010-1304-0 PMid:20960149

12. Zielinski MD, Thomsen KM, Polites SF, Khasawneh MA, Jenkins DH, Habermann EB. Is the centers for Medicare and Medicaid service's lack of reimbursement for postoperative urinary tract infections in elderly emergency surgery patients justified? Surgery. 2014;156(4):1009-15. https://doi. org/10.1016/j.surg.2014.06.073 PMid:25239361

13. Flores-Mireles AL, Walker JN, Caparon M, Hultgren SJ. Urinary tract infections: Epidemiology, mechanisms of infection and treatment options. Nat Rev Microbiol. 2015;13(5):269-84. 
https://doi.org/10.1038/nrmicro3432

PMid:25853778

14. Qin C, Oliveira GD, Hackett NL, Kim JY. Surgical duration and risk of Urinary Tract Infection: An analysis of 1, 452, 369 patients using the national surgical quality improvement program (NSQIP). Int J Surg. 2015;20:107-12. https://doi.org/10.1016/j. ijsu.2015.05.051

PMid:26054658

15. Choudhury FR, Rashid M, Rumana R, Uddin AB, Ava NN. Short term versus long term catheterization after urogenital prolapse surgery. J Shaheed Suhrawardy Med Coll. 2011;3(2):41-3. https://doi.org/10.3329/jssmc.v3i2.12077

Author Queries???

AQ6: Kindly cite references 12 and 13 in the text part
16. Fattah AN, Santoso BI. Urinary catheterization in gynecological surgery: When should it be removed? Med J Indones. 2013;22:183-8. https://doi.org/10.13181/mji.v22i3.589

17. Huang $\mathrm{H}$, Dong $\mathrm{L}, \mathrm{Gu} \mathrm{L}$. The timing of urinary catheter removal after gynecologic surgery: A meta-analysis of randomized controlled trials. Medicine (Baltimore). 2020;99(2):e18710. https://doi.org/10.1097/md.0000000000018710 PMid:31914080

18. Kranz J, Schmidt S, Wagenlehner F, Schneidewind L. Catheterassociated urinary tract infections in adult patients. Dtsch Arzteb Int. 2020;117(6):83-8. https://doi.org/10.3238/arztebl.2020.0083 PMid:32102727 